Nadwa : Jurnal Pendidikan Islam

Vol. 13, No.2 (2019)

Accredited by Ristekdikti based on Decree No. 51/E/KPT/2017

DOI : $10.21580 /$ nw.2019.13.2.5184

\title{
The Implementation of Role of Kuttab Al-Fatih (KAF) Philosophy in Islamic Character Education
}

\section{Hafnidar}

Malikussaleh University, Aceh, Indonesia

hafnidar@unimal.ac.id

\section{Rosnidar Mansor}

Sultan Idris Education University, Tanjung Malim, Malaysia rosnidar@upsi.fpm.id

\section{Suppiah Nichiappan}

Sultan Idris Education University, Tanjung Malim, Malaysia suppiah@upsi.fpm.id

\section{Abstract}

The aim of study was to understand about the implementation of role of kuttab al fatih (KAF) philosophy in islamic character education. This research used qualitative method. The study revealed that the KAF philosophies are "the faith before the Quran" "the adab before the knowledge" and "the knowledge before the actions ('amal), which are believed to aid KAF to achieve its vision and mission. The implementation of KAF Philosophies in Islamic character education creates a solid foundation of faith which contains basic values for students who contain character good personalities such as obedient, responsible, disciplined, hard-working, long term concentration or focus, away from prohibitions, vices, sincere, be grateful, and motivated because of Allah. KAF philosophies delivered to all parties in KAF included students, parents, teachers, management, staff Foundation, cleaning service and driver.

Keywords: Implementation; Islamic character education, Islamic education, kuttab, obedient; responsible;

\section{Abstrak}

Tujuan dari penelitian ini adalah untuk memahami tentang implementasi peran filosofi kuttab al fatih dalam pendidikan karakter Islami. Penelitian ini menggunakan metode kualitatif. Studi ini mengungkapkan bahwa filosofi KAF adalah "Iman sebelum Quran" "Adab sebelum Ilmu""Ilmu sebelum tindakan (amal), yang diyakini membantu KAF untuk mencapai visi dan misinya. Penerapan KAF Philosophies dalam pendidikan karakter Islam menciptakan fondasi iman yang solid yang berisi nilai-nilai dasar bagi siswa yang mengandung karakter kepribadian yang baik seperti taat, 
bertanggungjawab, disiplin, pekerja keras, konsentrasi atau fokus jangka panjang, jauh dari larangan, kejahatan, tulus, bersyukur, dan termotivasi karena Allah. Filosofi KAF disampaikan kepada semua pihak di KAF termasuk siswa, orang tua, guru, manajemen, staf Yayasan, layanan kebersihan dan sopir.

Kata Kunci: impelemntasi; pendidikan karakter Islami, filosofi; akhlak; taat; tanggungjawab;

\section{Introduction}

The subsequent cultural differences in educational philosophy used between western and eastern nations. The rationalism has given secularism in knowledge, which separates knowledge and theology. Secularism has influenced the educational curriculum system throughout the world including Malaysia - also Indonesia - through the influence of colonialism. 1 The colonialism has done the process of acculturation to the secularism values. 2

However, the importance of character education has been at the core of educational philosophies, in Western history to the times of Plato.4. In Muslim history, the core of educational philosophies starting from Muhammad SAW inaugurated as the prophet. The question is how to develop good character. Likewise, the need to examine what is character inculcated of character education in schools. 3

1 Abdul Hafiz Mat Tuah \& Zakaria Stapa. Pendekatan falsafah sains alquran dalam kurikulum pendidikan kebangsaan (Jurnal Usuluddin, 2015), 23 (2), 143-154.

2 Bassam Tibi, The Crisis of Modern Islam: A Preindustrial Culture in The Scientific Technological Age. (Terjemahan oleh Yudian W. Asmin. Yogyakarta: Tiara Wacana Yogya, 2014).

3 D. Park, Tsukayama, E., Goodwin, G. P., Patrick, S., \& Duckworth, A. L., A tripartite taxonomy of character: Evidence for intrapersonal, interpersonal, and intellectual competencies in children (Contemporary Educational Psychology, 2017) 48, 16-27. 
Kuttab Al Fatih (KAF) is one basic educational institution for ages 5 to 12 years, established in 2012 in Depok, Indonesia. KAF with reference to the original Kuttab curriculum used by the Prophet Muhammad Saw and the companions. KAF curriculum carries out the goals of Indonesia National curriculum, written in the 1945 Constitution and Long Term Development Plan (RPJP) $2005-2025$, namely "to educate the life of the nation and develop a completely integrated Indonesian". 4

$\mathrm{KAF}$ is unique in implementing character education. The KAF students can memorize Quran in many chapters, academic achievement and also good in social interaction.

\section{How Important of Philosophy in Character Education}

Etymologically, philosophy comes from Arabic which means the study of wisdom. In English, the word philosophy comes from the Greek word, Philosophia, where philo means love or want, and sophia means wisdom, clever, deep understanding. Hence, philosophy is the deep desire to attain wisdom or to be wise.

A number of prominent said that he implementation of character education must be carried out in line with the philosophy of the school.5 The vision and mission of the school must be based on philosophy.6 One of Scholar described vision as an idea that includes everything including organizational values and philosophy as an interesting and inspiring guide. Vision emphasizes change, ideal future conditions and has a

4 Indonesia Constitution, 1945.

5 Dishon, G., \& Goodman, J. F., No-excuses for character: A critique of character education in no-excuses charter schools (Theory and Research in Education, 2017) 15 (2).

6 Kay, K. (2009). Middle schools preparing young people for 21st century life and work. Middle School Journal, 40(5), 41-45. 
238 | Hafnidar. etc

longer time span than strategy.7 Grounding the organization's vision in ideals and values help leaders to convince their followers to strive for the organization future and encourage individual and organizational performance. 8

Actually, the primary school mission is to prepare students for learning, while the middle school mission is to make students ready for college and career. There are basic values that must be placed carefully and substantially while in elementary school because teaching grades in elementary school can prepare students to be ready to learn in the next level. Therefore, there is importance to establishing character education whether a school is a place where values is taught or not.9

Besides that, Humanistic theory describes the philosophy of character education should be discovered and understand the values of the nation's character as the basic for actions through the process of internalization and avoid indoctrination. Based on this theory, the initial concept is a component of philosophy of character education aims to humanizing human, which is called humanistic education. 10 This concludes that the humanistic theories applied in character education is based on the humanistic philosophy.

7 Kubokawa, A., \& Ottaway, A., Positive psychology and cultural sensitivity: A review of the literature Graduate (Journal of Counseling Psychology, 2009) 1 (2), 130-138.

8 Crossan, M., et al,.Developing leadership character in business programs (Academy of Management Learning and Education, 2013) 12 (2), 285-305

9 Elias, M. J., The future of character education and social-emotional learning: The need for whole school and community-linked approaches (Journal of Character Education, 2014) 10 (1), 37-42.

10 Uljens, M., \& Ylimaki, R. M. Bridging educational leadership (curriculum theory and didaktik, 2017) 5. 


\section{The Implementation of Role of Kuttab Al Fatih (KAF) Philosophy}

Teachers, students, principal, parents, and foundation counselor mentions that KAF's philosophy is: (1) Faith before the Quran; (2) Adab before knowledge. Only the male students and foundation counselor added the third point which is (3) Knowledge before actions. The philosophy of Faith before the Quran and $a d a b$ before knowledge contains the meaning as stated in the following transcript of the interview: "learn faith first before the Quran, if the faith has been formed, the faith will be further developed when studying the Quran".11 "faith before the Quran means one must be ready with faith before learning Quran, $a d a b$ before knowledge means learn first and then gain knowledge and having some knowledge should be with $a d a b " .12$

Faith, $a d a b$, and Quran have become the fundamental philosophy of KAF character education implementation. In KAF, faith character is encouraged by studying $a d a b$ and Quran. The KAF philosophies are "the faith before the Quran","the adab before the knowledge" , and "the knowledge before the action (Arabic : amal)".

The study finding that students, teachers, parents, and principal understood the term "character" as "adab". Some of them said: "Here in KAF, it is more to their adab, how they should behave to older people, teachers, friends, the opposite sex, that's what I know". 13 "That character is adab, in other schools there is the term Islamic character" 14 "The character is adab, the nature and behavior" 15 "Faith in God is the essence, adab is a

11Interview with (1SM-29:30)

12 Interview with (2SF-7:8).

13 Interview with (12TeacherQ1-14:15);

14Interview with (13TeacherQ2-123);

15 Interview with (2StudentF-17); 
240 | Hafnidar. etc

derivative. After the child has a good faith, follows Quran, follow the sahabat, he will have a good character" Whereas, the term "character" understood by students, teachers, and parents is the output of various variables of faith that exist in humans as revealed by foundation counselor.

It can be concluded that the term "character" understood and perceived by KAF in this study is the faith character produced by faith that implemented through $a d a b$ and studying Quran. The KAF philosophy understood by participants of this study is a principle that underlies the implementation of character education in $\mathrm{KAF}$.

\section{The important of KAF Philosophies}

The study findings concluded that the implementation of character education in KAF is based on faith as the main foundation. This has produced individuals who have the character of faith. Faith character can be described as the character of believers that is built innately as a result of psychological processes on having faith to Allah, apostle, Book of Allah, destiny from Allah, and the last day or also known as faith in the six pillars of Islamic faith.

Faith character is encouraged by studying $a d a b$ and Quran. Every student is taught that strong faith can lead to achieving good $a d a b$ and studying Quran. The aims of studying Quran are to read, remember, understand and practice in life, whereas $a d a b$ is to achieve spiritual, intellectual, and physical discipline especially from parents and teachers in maintaining faith spirit and maximizing the golden age to inculcated faith and $a d a b$.

Studying $a d a b$ and Quran produce many good personalities such as submissive, obedient, responsible, disciplined, hard-working, diligent, long term concentration or focus, away from prohibitions, vices, sincere, be grateful, and 
motivated because of Allah. Therefore, faith, adab, and Quran have become the fundamental philosophy of the implementation of character education in KAF which is also part of the institution's philosophy, vision and mission.

The visions of KAF are that the students will: 1) becomes good children, 2) be a dedicated leader, 3) be farthest from hell and nearer the heaven. The vision of KAF has aspired that it can be achieved through the curriculum of character education implementation. Meanwhile, the KAF philosophies become spirit of all parties in KAF to achieve KAF vision and mission.

\section{The KAF Philosophies Delivery Methods}

All parties like teachers, students, parents, school and foundation management i.e. principal, manager, counselor as well as support system parties i.e. driver, teachers baby sisters, and cleaning services got information about the KAF philosophy through various methods, namely:

$\checkmark$ Knowledge sharing. The interview and focus group discussion revealed that all parents, teachers, students, principal and director said that knowledge sharing was one of the tools most often used to disseminate information about the KAF philosophy. Some of them stated that: "know from tag-line because it's often mentioned by a teacher, when make a pledge, when they are advised" 16; "in the book, in the Kuttab book.

During training, $a d a b$ before knowledge and faith before the Quran is the norm". 17 "At the time of the registration process ... there are Stadium General, twice; the details are conveyed in the first stage, some proceeded to stage 2, more details are explained". 18 "Through the study ... there is once a month

16 Interview with (2 Student F-4:5)

17 Interview with (13TeacherQ2-16);

18 Interview with (14Principal-87:89); 


\section{2 | Hafnidar. etc}

study for parents that is mandatory. I can get a lot of parenting concepts in the Kuttab too. I like to read the tag line. Kind of changing our mindset in nabawiyah parenting" 19and some others said that:

Before becoming a teacher there was a training ... where the teachers are to have the same vision, to be able to instill faith and adab to every student" ... the Qur'an is never to be abandoned ... These three things are always interrelated... . KAF conveyed the philosophy of character education also through meetings, but not every meeting always discussed that. 20

For recruitment, you have to take part in training. the teacher will already have teaching experience. To every teacher who joins the Kuttab, we give training, knowledge, groundwork, and foundation related to the Kuttab .... starting from the 4 th batch, there is a teacher academy, a total of 6 months, every Sunday full, that was the end of 2014-2015. The teacher academy 1 was like that, academy 2 to 5 is 2 years, on Fridays and Saturdays the instruction are full day, only on Friday half a day. Next January academy 5 begins... This teacher academy is the place to produce teachers, so the output is a teacher ... and philosophy becomes a compulsory subject within the teacher academy in KAF.21

Besides, based on observed the prospective teacher who was studying at the KAF teacher academy,22 the KAF philosophy mentioned by one of the Ustadz, who gave a briefing at the

\footnotetext{
19 Interview with (3ParentM1-39-41);

20 (11TeacherC2-58:62).

21 Interview with (14Principal-50:65)

22 Interview with (Obs 7-24.11.2018-1:7),
} 
morning pledge. 23 In addition, the researcher also observed a night camp referred as, Mabit for teachers. Mabit activities are conducted as a means of repeating information about the KAF philosophy 24

Accordingly, it can be concluded that the knowledge forum is used to disseminate information about the KAFphilosophy. There are monthly compulsory study, non-mandatory studies, and non-parenting meeting for the parents. Furthermore, KAF also provided training before becoming a teacher, teacher meetings, teacher academy, and everyday forum for the teachers.

$\checkmark \quad$ Print media. The interviews and focus group discussions revealed that all parents, teachers, teachers, students, principal and founders of the foundation mentioned that the print media is one of the main media used in KAF in the attempt to the KAF philosophies as revealed in the following interview transcript: "by reading the Kuttab Module"; 25"I know it from the Ustadz/zah, from the Kuttab book, the parental module, from the notebook or the banners when camping or other event, the Quran meaning book" 26and some others said that:

"Through advice, explanations in class, there is a tadabbur module, from stories, from reading siroh nabawyah books but it is an initiative of its own but sometimes it is recommended by the Kuttab, from BBO. 27 "... Every new teacher must read the Kuttab module, then read it again (repeated reading) and continue to be repeated every

23Interview with (Obs 5-23.11.2018-1:5).

24 Interview with (Obs 6-23.11.2018-1:5).

25 Interview with (3ParentM1-39

26Interview with (1StudentM-12-14);

27 Interview with (2StudentF-47:49). 


\section{4 | Hafnidar. etc}

chapter. The module should be submitted to the Kuttab, there are times when we also asked for presentation. After this is finished, they read the siroh nabawiyah, darri rawaihul maktum, Sheikh Syauqi Rahman Al Mubarraquri that is to be read to completion. We give a target to finish the siroh. The purpose of reading the siroh is because the application and running the quran and hadith can be obtained through the siroh ... our insight will increase related to the adaptation of the apostle with relatives, adaptation to Arabic badui, adaptation to friends, adaptation and rasulullah's interactions with the ones that are against him, the Christians ... " 28

Accordingly, it can be concluded that print media is one of the media used to disseminate information about the KAF including the philosophy. The print media that is often used is the Kuttab Module, parental modules, event banners, and study with parent modules or BBO.

$\checkmark \quad$ Electronic media. Electronic media is often used as a mean to socialize the concept of the KAF including the philosophy of character education in the KAF as revealed in the following interview transcript: "it is usually mentioned in chat groups for parents (WhatsApp group). Usually the class leader is the one who is sounding ... "29 "the teachers are not obliged to read on the website, just be as often they can, it is up to them. Ustadz Budi's DVD, Telegram and Youtube video" 30

It can be concluded that the electronic media that are often used to disseminate information about the KAF philosophy are the parents' Whatsapp group, KAF website, KAF

28 Interview with (14Principal-67:87).

29 Interview with (5ParentM3:48:49);

30 Interview with (5ParentM3:48:49). 
Facebook, and Ustadz Budi DVD, Telegram and YouTube video. Finally, the following figure show the summary of delivery methods of KAF philosophy

\section{Discussion}

The philosophy of "faith before the Quran" came from the words of Prophet Muhammad (Hadith) that said that Jundub bin Abdillah said: "We were with the Prophet when we were teenagers; we studied faith before the Qur'an. Then when we studied the Qur'an, our faith increased.31 Then in the history of Thabrani in al Mu'jam al Kabir and al Baihaqi in Syu'ab al Iman, there is an additional sentence of Jundub, "As for you today learn the Qur'an before Faith". Directly, this sentence is addressed by Jundub to the following generation (Arabic: Tabi'in). Thus, it is clearly seen from the sentence of the Prophet, that there was a sign of decreasing quality from Sahabat to Tabi'in, and this was immediately felt by the Companions after the Prophet's death, when they interacted directly with the generation of Tabi'in. 16

Furthermore, from the Jundub sentence above, we can know decline of generation value comes from the reversal of the order of learning life skills. Companions of the Prophet have studied Faith before the Qur'an while Tabi'in studied the Qur'an before Faith. Even though the generation of Tabi'in is a very powerful generation where in Islam they have prospered through its civilization.

The KAF board have seen today's problems is greater than the reversal of learning. 32 The combination of faith and the Quran will produce a strong personality, in which this is the Real Islamic Character Building. Meanwhile, the KAF philosophy is the words from the ulama. Ulama often say, "Al iman qablal quran; Al adab

31 (Sunan Ibnu Majah no. 60, verified by al-Albani).

32 Budi Ashari \& Muhammad Ilham Sembodo. (2012). Modul Kuttab. Yayasan Al-Fatih. 


\section{6 | Hafnidar. etc}

qablal 'ilmu; al ilmu qablal amal" meaning faith before the Quran, $a d a b$ before knowledge, and knowledge before actions. The sentence has become the standard of Islamic education since ancient times, and has represented all character terms in it.

The importance of KAF philosophy in the character education implementation in KAF is related to the character shown by the students and teachers daily. Faith before the Qur'an implies that strengthening the faith is very important before learning the Qur'an intensely. This does not mean that novice students should not learn the Quran before their faith is strong, but it implies that the intensity and priority of learning of faith must be stronger than learning the Quran. Likewise, the philosophy of "adab before knowledge" is where students continue to study knowledge since the beginning of learning in the Kuttab, but the intensity, priorities and capacity of knowledge learned are still limited because the KAF curriculum still prioritizes on faith and $a d a b$.

It is worth discussing the following interesting facts revealed by the results of this study. Every time teachers at KAF go to class to teach, they will first pay attention to the "adab" side. The teachers will refuse to start the class if the $a d a b$ of the students is not good because it shows that the students are not ready to learn. The urgency of $a d a b$ for students in pursuing knowledge is a reason that helps a person gain knowledge. Ibn Zakariya An Anbari rahimahullah, said:

Knowledge without $a d a b$ is like fire without firewood, and $a d a b$ without knowledge like a body without spirit (Arabic: adabul Imla 'wal Istimla'). In addition, Yusuf bin Al Husayn rahimahullah said "With adab, you will understand knowledge (Arabic: Iqtidhaul Ilmi Al 'Amal)" (Min Washaya 
Al Ulama li Thalabatil Ilmi). Imam Malik rahimahullah (AsySyakir, 2018) said "Learn adab before learning knowledge".33 Besides, KAF's philosophy, vision and mission are interrelated and are equally sourced from the Al Quran and Sunnah. KAF's vision is to have students who will become devoted leaders, farthest from hell and are included in heaven. To achieve this vision, KAF arranged a number of missions through a character education curriculum based on the philosophy of "adab before knowledge, faith before the Qur'an, knowledge before actions".

The KAF philosophy in character education implementation contains basic values that are important and substantial for students' readiness to learn. KAF is in charge of preparing a solid foundation of faith so that it can construct character of faith.

The findings of current study are consistent with a number of previous research who said that it is important to look into the future to ascertain what the goals of the school are, and should be a place where values are taught. 34 Kay $(2009 ; 2016)$ has mentioned that the primary school vision and mission should be constructed to encourage students learning, while secondary schools vision should prepare their students for college and careers. While, teaching values can help elementary schools in their mission to prepare their students for learning.

The KAF philosophy is a principle that underlies the implementation of character education in the KAF, all parties known the KAF Philosophy thorough various delivery methods such knowledge sharing forums, print media, and electronic media that shown though offline and online. This study found that

33 Asy-Syakir, M. I., Kajian Ringan Tentang Ibnu Majah dan Kitab Sunannya (Sunan Ibni Majah) (Academia, 2018).

34 Gurley, Peters, Collins, and Fifolt (2015) 
248 | Hafnidar. etc

the implementation of character education must be carried out in line with the school's philosophy, in line with the previous study. 35

\section{Conclusion}

The KAF philosophies are "the faith before the Quran", "adab before knowledge"and "the knowledge before the actions". The KAF philosophies is a principle that underlies the character education implementation. Faith, $a d a b$, and Quran have become the fundamental philosophy of KAF. The significance of KAF Philosophies in character education implementation related the role of faith that produced faith character that implement through $a d a b$ and studying Quran. The faith character content in vision, mission, and philosophy of KAF. Accordingly KAF Philosophies delivered to students, parents, teachers, principal, foundation counselor and others parties through knowledge sharing forums, print media, and electronic media.

Studying adab and Quran can produce many good personalities such as submissive, obedient, responsible, disciplined, hard-working, diligent, long term concentration or focus, away from prohibitions, vices, sincere, be grateful, and motivated because of Allah. Therefore, faith, $a d a b$, and Quran have become the fundamental philosophy of the implementation of character education in KAF which is also part of the institution's philosophy, vision and mission.

35 Ildefonso-Sanchez, G. M., Revaluing Leisure in Philosophy and Education. Studies in Philosophy and Education, 2019) 38(2), 163-176. Bonnett, M., Environmental Consciousness, Sustainability, and the Character of Philosophy of Education. (Studies in Philosophy and Education, 2017) 36(3), 333-347. Li, Y., \& Lerner, R. M. (2011). Trajectories of school engagement during adolescence: implications for grades, depression, delinquency, and substance use. Developmental psychology, 47(1), 233. 
Hafnidar, etc | 249

\section{References}

Abdul Hafiz Mat Tuah \& Zakaria Stapa. Pendekatan falsafah

sains al-quran dalam kurikulum pendidikan kebangsaan

,Jurnal Usuluddin, 2015), 23 (2), 143-154.

Asy-Syakir, M. I., Kajian Ringan Tentang Ibnu Majah dan Kitab Sunannya (Sunan Ibni Majah) (Academia, 2018).

Bonnett, M., Environmental Consciousness, Sustainability, and the Character of Philosophy of Education. (Studies in Philosophy and Education, 2017) 36(3), 333-347.

Budi Ashari \& Muhammad Ilham Sembodo. Modul Kuttab. Yayasan Al-Fatih. 2012.

Crossan, M., et al,.Developing leadership character in business programs (Academy of Management Learning and Education, 2013) 12 (2), 285-305

Dishon, G., \& Goodman, J. F., No-excuses for character: A critique of character education in no-excuses charter schools, Theory and Research in Education, 2017

Elias, M. J., The future of character education and social-emotional learning: The need for whole school and community-linked approaches (Journal of Character Education, 2014) 10 (1), 3742

Etherington, M., Values education: Why the teaching of values is necessary, but not sufficient (Journal of Research on Christian Education, 2013) 22, 189-210.

Gurley, Peters, Collins, and Fifolt, 2015.

Ildefonso-Sanchez, G. M., Revaluing Leisure in Philosophy and Education. Studies in Philosophy and Education, 2019) 38(2), 163-176.

Kay, K. Middle schools preparing young people for 21 st century life and work. Middle School Journal, 40(5), (2009). 41-45. 
250 | Hafnidar. etc

Kubokawa, A., \& Ottaway, A., Positive psychology and cultural sensitivity: A review of the literature Graduate (Journal of Counseling Psychology, 2009) 1 (2), 130-138.

Li, Y., \& Lerner, R. M. (2011). Trajectories of school engagement during adolescence: implications for grades, depression, delinquency, and substance use. Developmental psychology, 47(1), 233.

Park, D., Tsukayama, E., Goodwin, G. P., Patrick, S., \& Duckworth, A. L., A tripartite taxonomy of character: Evidence for intrapersonal, interpersonal, and intellectual competencies in children (Contemporary Educational Psychology, 2017) 48, 16-27.

Tibi, Bassam. The Crisis of Modern Islam: A Preindustrial Culture in The Scientific Technological Age. Terjemahan oleh Yudian W. Asmin. Yogyakarta: Tiara Wacana Yogya, 2014.

Uljens, M., \& Ylimaki, R. M. Bridging educational leadership (curriculum theory and didaktik, 2017. 